\title{
Agricultural Development and Emplyoment Generation: The Nigeria Experience.
}

\author{
Ogbalubi, L.N And Wokocha,C.C
}

\begin{abstract}
This paper examines Agricultural Development and employment generation with particular reference to Nigeria. The paper acknowledged the important role agriculture plays in developing countries such as Nigeria not only in employment generation but also for overall economic growth. It showcases the agriculture sector as the most critical and basic sector that has significant potentials for the transformation of the Nigerian economy. It provides the overview of agricultural development in Nigeria and also provides a framework for understanding the agricultural sector in relation to the strategies employed by government to develop the sector.The paper further acknowledged that although most public policies in Nigeria have been tailored towards food security, supply of agricultural raw materials needed by the manufacturing sector to provide adequate employment and income. However, the potential of the sector is yet to be maximised. In assessing the growth of agricultural sector in Nigeria and impact in employment, data were obtained from Central bank of Nigeria and Federal Office of Statistics. This paper also identifies some major factors constraining the development of agricultural sector in Nigeria such as neglect of agriculture arising from the discovery of oil, inadequate infrastructural facilities, inadequate extension services, shortage of labour to rural- urban migration, decline quality of land because of oil activities in the Niger Delta Region, Policy inconsistency etc. The paper recommends the provision of credit facilities to farmers, extension services, price stabilization and making agriculture a priority e.tc to ensure that the sector takes its rightful place in our economy.
\end{abstract}

\section{Introduction:}

Agriculture is the mainstay of many economies. All over the world, the development of an enduring economy goes hand in hand with agricultural development. Agriculture is considered a catalyst for the overall development of any nation. It is thus a critical sector that drives the economic development and industrialization of the developing nation, and also holds the ace for reducing unemployment. Thus, its' development is critically important for ensuring food and nutritional security, income and employment generation, and for stimulating industrialization and overall economic development of the country.

The technological strides recorded by the world's leading economies had their roots in agriculture. Despite the fact that the sector has increasingly shrunk in its contribution to the Gross Domestic product (GDP) of many nations, it still provides the chunks of the GDP of many nations especially the developing ones.

Development economists have always assigned the agriculture sector a central place in the development process, however the understanding of that role has evolved overtime. Early development theorists emphasized industrialization, though they counted on agriculture to provide the necessary output of food and raw materials, along with the labour force that would gradually be absorbed by industry. Much later thinking moved agriculture more to the forefront of the development process; the hopes for technical change in agriculture and "green revolution" suggested that agriculture could be the dynamo for growth, (Wilber \& Jameson, 1992).

The industrial revolution of the Nineteenth century which catapulted the agrarian economies of the most countries of Europe got the impetus in Agriculture (Ojenagbo, 2011). Indeed, the importance of agriculture in any nation's economy cannot be over emphasised. For instance in United States of America, agriculture contributes about $1.1 \%$ of the country's Gross Domestic Product. It is $13 \%$ of the in China, $2.6 \%$ in Australia, 9\% in South Africa, $2.5 \%$ in Isreal, $12 \%$ in Australia, $9 \%$ in Argentina, $13.5 \%$ in Egypt and in Nigeria it contributes $26.8 \%$ of the country's Gross Domestic Product. Similarly, agriculture provides major source of employment in most developing countries, accounting for $25 \%$ of the work force in Brazil, $32 \%$ in Egypt, 3.7 $\%$ in Israel, $70 \%$ in Nigeria. The above statistics is an indication that the more developed a country is, the lower the contribution of agriculture to Gross Domestic Product.

In practical terms, agriculture has worked a tremendous miracle in countries like Mexico, India and China where the Green Revolution is one of the great success stories of modern times. It is the major contributor to the export -led growth pattern of a country like Taiwan which was able to attain notable increases in per capita GNP. Again, according to Wilber \& Jameson (1992), Chile's recent rapid growth has been largely attributed to agricultural exports. In his book titled " The End of Poverty" Jeffrey Sachs describes how the Rockefeller Foundation, fearing the grim possibility of massive hunger because of rapidly rising global 
population, began developing and promoting high yield varieties of staple crops, first as a pilot project in Mexico, and then replicated it in Asia.

As a result of the replication of this Green Revolution in Asia, India went from eleven metric tonnes of wheat production in 1960 to twenty -four million tonnes in 1970, thirty -six million tonnes in 1980, and fifty five millions in 1990. This also worked wonders in the Philippines and peru. Similarly, in China, agriculture led the way to the emergence of this Asian giant as a major force in the world economy. This is especially remarkable when you consider that China, with a population of over 1.3 billion people, is able to produce enough food for her people, and yet has more than enough extra to make her a major exporter of agricultural produce to the world. It opens up the economy as it provides the necessary raw materials for the industries. In all these, tremendous employment opportunities were created.

Thus, the importance of the agricultural sector in generating employment and stimulating overall economic development in a developing country such as Nigeria is cannot be undermined. Most public policies in Nigeria, especially since independence in 1960, were tailored towards promoting food security, provision of the agricultural raw materials needed by the manufacturing sector to provide adequate employment and income to alleviate poverty as well as earn substantial foreign exchange.

In sub- Saharan Africa, Agriculture occupies a prominent position in the national economies, as the sector serves as a key driver of growth, wealth creation,employment as well as poverty reduction. It is also the leading economic activity in the continent which contributes between $20 \%$ and $30 \%$ of its Gross Domestic Product.

In an agrarian economy like Nigeria, the land as a unit for agricultural production provides the needed fulcrum upon which a sustainable development would blossom. Agricultural production till date remains the mainstay of the Nigerian economy. With a population that is largely agrarian, agriculture has traditionally been the main sources of livelihood for our people. It provides the means of livelihood for over $70 \%$ of the population and a major source of raw materials for the agro-allied industries and potent source of the much needed foreign exchange (World Bank, 1998, Okumadewa, 1997). The agricultural sector after independence, dominated the Nigerian economy, such that the development of the region was hinged on the sector alone. Agriculture accounted for about two-thirds of the Gross Domestic Product (GDP).

However, over the years, the sector has witnessed rapid decline in its role and contribution to national development.Hoes have been abandoned in pursuit of the black gold.This situation started with the ''Oil boom" which led to the rapid decline of the Agricultural sector.Consequently, Nigeria became a major importer of agricultural products as against its earlier position as a major exporter.This led to a decline of the economically active population in agriculture in Nigeria as well as an increase in the level of unemployment,in the region.

In the late 1970s, Nigeria began its own Green Revolution amidst fanfare, soon after, the programme collapsed and the country lapsed back to its unenviable status of a major importer of grains and processed foods. For a country which once earned most of its foreign exchange from agriculture, which taught Malaysia how to produce palm, it is a sad irony,that, the Nigeria Green Revolution failed due to, among others, a misapplication of funds, insincerity, absolute neglect and a general high level of nationalism

Development economists have in fact attributed the present economic situation in the country to the poor performance of the agriculture sector. The near eclipse of the sector in the era of oil boom (1972- 1975), has been described as the most serious damage done to agricultural sector in Nigeria. The Knowledge of Nigeria agricultural production landscape as noticed by (Okuneye, 1995), has shown that the small scale farmers that dominate the production landscape, produce about $85 \%$ of total production. These small scale farmers were characterized by strong dependence on agricultural labour market, little or no forms of savings or storage facilities, unfavourable and cultural practices adopted and high cost of labour. The socio economic and production characteristics of the farmers, inconsistent and unfocused government policies as well as inadequate infrastructural base (road networking/bad transportation system), all combined to choke the sector, resulting in low production and consequently high prices of food items. This invariably affected the level of unemployment in the country.

Another cause of decline in agriculture in Nigeria is the widening technology gap in agriculture itself which results in low labour productivity, and an equally widening rural -urban income gap which promotes rural urban drift. Apart from these, other factors include: problems connected with high demand for imported goods which affect the demand for domestic goods.

Based on its climatic and agro-ecological conditions, Nigeria has potentials to produce a wide variety of crops. While the Northern part can guarantee the production of cereals such as sorghum, maize, millet, and other crops like cotton, cowpea, groundnut; the Middle belt and the Southern parts of the country have potentials to produce roots/ tubers such as cassava, yam, cocoyam and other crops like plantain as well as maize.The production of these crops, have the potential to create employment opportunities for the unemployed labour force both in their cultivation, processing and marketing. 


\section{OVERVIEW OF NIGERIAN AGRICULTURE SECTOR}

Although, Nigeria today depends heavily on oil industry for its revenue, it is still predominantly an agricultural society. Agriculture remains a key sector of the economy providing employment for about $70 \%$ of the population. The bulk of this population are engaged in agricultural production at a subsistence level; the holdings are generally small and scattered. The Federal office of statistics in its' 1999 reports indicated that agriculture sector provided $41 \%$ of Nigeria's total gross domestic product (GDP) in that year. This represented a decrease of $24.7 \%$ from its contribution of $65.7 \%$ to the GDP in 1957.

Nigeria's enabling of climate allows it to produce a variety of food and cash crops. The staple food crops include cassava, yam, corn, coco-yam, cow-peas, beans, sweet potatoes, millet, plantain, banana, rice, sorghum, and a variety of fruits and vegetable. The leading cash crops are cocoa, citrus, cotton, groundnut (peanuts), oil palm, and rubber. They were also Nigeria's major export in the 1960s and early 1970s until oil took over as the major source of the country's revenue. Among major export destinations for Nigeria agricultural export products were Britain, United States, Canada, France and Germany.

A significant portion of the agricultural sector in Nigeria involves cattle rearing, fishery, poultry, lumbering, which contributed more than $2 \%$ to the gross domestic product (GDP) in the 1980s. According to the United Nation Food and Agriculture Organization (1987), estimate, there were 12.2million cattle, 13.2 million sheep, 26.0 million goats, 1.3 million pigs, 700,000 donkeys, 250,000 horses and 18,000 camels, mostly in Northern part of Nigeria, and owned mostly by rural dwellers rather than by commercial companies. Fisheries output ranged from 600,000 to 700,000 tons annually in the 1970s. Estimates indicated that the output had fallen to 120,000 tons of fish per year as at 1990 , and this has continually declined. This is related strongly to the environmental degradation and water pollution in the Niger Delta Region caused by oil exploration activities. The output is however, experiencing rapid increase since 2006. This increase was initiated by the encouragement and training of farmers in the Niger Delta by the Green River Project of the Nigerian Agip Oil Company Limited (NAOC).

As noted earlier, the decline in agricultural production in Nigeria began with the advent of oil boom in the early 1970s, which resulted in the neglect of the agricultural sector. The oil boom in the oil sector brought about a distortion in the labour market. This distortion in turn produced rippling adverse effects on the production levels of both food and cash crops. Government had paid farmers low prices over the years on the food for the domestic market in order to satisfy urban demands for cheap basic food products. This policy, in turn, progressively made agricultural work unattractive and enhanced the lure of the cities for farm workers. Collectively, these developments worsened the low productivity, both per unit of land and per worker, due to several factors: inadequate technology,poor transportation, environmental degradation, and infrastructure, and trade restrictions.

However, as food production could not keep pace with its increasing population, Nigeria began to import food. It thus lost its status as exporter of such cash crops as cocoa, palm oil, and groundnuts. According to United State Department of State FY2001 Country Commercial Guide, Nigeria's total food and agricultural imports are valued at approximately 1.6 million per year.

The major imports from the United States are wheat, sugar, milk powder, and consumer ready food products. However, efforts been made since late 1970s to revive agriculture so as to make Nigeria food selfsufficient again, generate employment and increase the export of agricultural products have only produced modest results. These efforts have only produced modest result.

\section{AGRICULTURAL DEVELOPMENT IN NIGERIA :}

At independence, Nigeria operated a mixed economy. Her prospect for economic growth was heightened by the dependence on both oil and agriculture. Farming, livestock production, forestry and fishery contributed more than $66 \%$ of the country's GDP. At the same period, Nigeria was the world's largest exporter of groundnut and palm produce and the third largest producer and exporter of cocoa. The diversity of these natural resources gave each region a mark of identity. For example, palm produce was largely grown in the East, cocoa in the West and groundnut in the North.

Successive governments of Nigeria have introduced various agricultural programmes since independence to promote agriculture, in order to generate employment, stimulate industrialization and overall economic development of Nigeria.

The 1962-1968 Agricultural Development Plan was Nigeria's first national plan. The key objective among others was emphasis on the introduction of more modern methods through farm settlements co-operation (nucleus) plantations, supply of improved farm implements (e.g. hydraulic hand presses for oil palm processing) and a greatly expended agricultural extension service.Some of the specialised development schemes initiated or implemented during this period included (i) Farm Settlement Scheme and (ii) National Accelerated Food Production Programme (NAFPP), launched in 1972.

There were also a number of agricultural development intervention experiments, notably 
(i) Operation Feed the Nation, launched in 1976

(ii) River Basin and Rural Development Authorities established in 1976

(iii)Green Revolution Programme, inaugurated in 1980, and

(iv)The World Bank-funded Agricultural Development Projects

While each of the above programmes sought to improve food production, the ADPs represented the first major practical demonstration of the integrated approach to agricultural development in Nigeria. The experiment which started with World Bank funding with projects at Funtua,(1974), Gusau (1974) and Gombe (1974), blossomed into Ayangba (1977), Lafia (1977), Bida (1979), Ilorin (1980), Ekiti - Akoko(1981 and Oyo-North (1982)agricultural development projects. Following the successful negotiations for multi-state agricultural development projects with World Bank, each state of the country, and the federal capital, Abuja, now has one ADP.

The years since the early 1960s also witnessed the establishment of several agricultural institutes and their extension research liaison services. Some of the major institutions are:

i) Agricultural Extension and Research stock Production and Fisheries production in Nigeria Liaison services (AERLS), at AhmaduBello University, Zaria

ii) The International Institute of Tropical Agriculture (IITA), Ibadan

iii) International Livestock Centre for Africa (ILCA)

iv) Nigeria Institute for Oil Palm Research, Benin.

v) National Root Crop Research Institute Umudike, now a University

vi) National Cereal Crop Research Institute.

vii) Establishment of several Universities and Colleges of Agriculture.

The Fourth Development Plan was characterized by slow progress, with massive food importations. Subsequently, Structural Adjustment Programme was introduced in 1985/86 to deregulate and stimulate local production. This was followed by National Acceleration Crops production programme (NAICPP) in 1996 and the Agricultural and Rural Transformation programme (ARTP) in 2000.

The National Economic Empowerment Development Strategy (NEEDS) was introduced in 2003/2004; a reform that encourages private sector participations, with one of the cardinal objectives of encouraging agricultural development among others. The Presidential Initiative Programmes (being implemented within the framework of National Economic Empowerment Strategy (NEEDS) and many other externally supported programmes from FAO, UNIDO, WHO were directed towards increase in agricultural production and employment generation.

\section{AGRICULTURAL CREDIT SCHEMES}

In line with the objective of promoting agricultural development, the Federal government in conjunction with the Central Bank of Nigeria (CBN) introduced several credit schemes as follows:

i) Agricultural Credit Guarantee Scheme Fund (ACGSF), scheme.

The Agricultural Credit Guarantee Fund was established by Decree No 20 of 1977, and started operations in April, 1978. Its original share capital and paid-up capital were N100 million and N85.6million respectively. The Federal Government holds 60 percent and Central Bank of Nigeria, 40 Percent of the shares. The capital base of the scheme was increased to N3 Billion in March, 2001. The Fund guarantees credit facilities extended to farmers by banks up to 75Percent of the amount in default net any security realized. The Fund is managed by the Central Bank of Nigeria, which handles the day-to day operations of the scheme. The guidelines stipulated the eligible enterprises for which guarantees could be issued under the scheme.

However, between 1978 and 1989 when the government stipulated lending quotas for banks under the scheme, there was consistent increase in the lending portfolios of the banks to agriculture, but after the deregulation of the financial system, banks started shying away by reducing their loans to the sector due to the perceived risk. In order to reverse the declining trend several innovations and products were introduced under the scheme such as:

- $\quad$ the self -help group linkage Banking

- $\quad$ Trust Fund Model and

- Interest Draw Bank

ii) Agricultural Credit Support Scheme (ACSS)

The Agriculture Credit Support is an initiative of the Federal and Central Bank of Nigeria with the active support and participation of the Bankers' Committee. The Scheme has a prescribed fund of N50.0 billion. The Agriculture Credit Support was introduced to enable farmers exploit the untapped potentials of Nigeria's agriculture sector, reduce inflation, lower the cost of agricultural production (i.e. food items), generate surplus 
for export, increase Nigeria's foreign earnings as well as diversify its revenue base. At national level, the scheme operates through a Central Implementation Committee (CIC) while at the Federal Capital Territory and States, the scheme operates through State Implementation Committees instituted to ensure that the objective of the scheme is realized without hindrance.

To access loans under this scheme, applicants (practicing farmers and agro-allied entrepreneurs with means) were encouraged to approach their banks for loan through their respective state chapters of farmers associations and State Implementation Committee. However, large scale farmers were allowed under the scheme to apply directly to the banks in accordance with the guidelines.

(iii) Commercial Agriculture Credit scheme

As part of its developmental role, the Central Bank of Nigeria (CBN) in collaboration with the Federal Ministry of Agriculture and Water Resources established the Commercial Agriculture Credit Scheme in 2009 to provide finance for the country's agricultural value chain (production, processing, storage and marketing) increased production arising from the intervention would moderate inflationary pressures and assist the Bank to achieve its goal of price stability in the country. The primary objectives of the scheme are to:

a) Fast -track the development of the agricultural sector of the Nigerian economy by providing credit facilities to large -scale commercial farmers at a single digit interest rate.

b) Enhance national food security by food supply and effecting lower agricultural produce and products prices, thereby promoting low food inflation.

c) Reduce the cost of credit in agricultural production to enable farmers exploit the cost the untapped potentials of the sector and

d) Increase output, generate employment, diversify Nigeria's revenue base, increase the level of foreign exchange earnings' and provide input for manufacturing and processing on a sustainable basis.

The scheme which is a sub-component of the Federal Government of Nigeria's Commercial Agriculture Programme is financed through a N200 billion Bond issued by the Debt Management office. Loans to be eligible entities under the Scheme were to be disbursed at a maximum interest of 9percent

Despite these laudable programmes, domestic food production is believed not enough to meet the geometric progression of the Nigeria population and at the same time provide agro-based industries with needed raw materials. Notwithstanding the efforts,made so far have attempted to provide an enabling environment,to getting back agricultural production to its rightful place. There is thus a strong need to sustain the current trend in the development of agriculture to a higher level if the challenges confronting the nation as regards food security and un-employment are to be overcome.

\section{AGRICULTURAL DEVELOPMENT STRATEGY:}

Nigeria's agricultural development strategy over the years has been centred round certain key policy areas and programmes which the country has pursued with expectation that these will lead to the development of the sector. Menyong et al (2003) outlined these policies:

\section{a) Agricultural Commodity Marketing and Pricing Policy}

The major instrument of agricultural commodity marketing and pricing policy was the establishment of six national commodity boards in 1997 to replace the regional, multi-commodity boards that had been operating since 1954. The six new national commodity boards were for cocoa, groundnut, palm produce, cotton, rubber, and food grains.

(b) Input Supply and Distribution Policy

Government policy on input supply and distribution focused on instrument for ensuring the adequate and orderly supply of modern inputs like fertilizers, agrochemicals, seeds, machinery and equipment and so on. The key policy instruments were:

i) Centralized Fertilizer Procurement and Distribution in 1975

ii) Creation of a National Agro- Service Centres to facilitate the distribution of modern inputs

iii) Creation of a National Seed service in 1972 to produce and multiply the improved seeds for rice, maize, cowpea, millet, sorghum, wheat e.tc

\section{c) Agricultural Input Subsidy Policy:}

This relates to subsidizing the prices of key inputs. This has been on from as far back as the 1950s, but in the early 1970 this policy became centralized Policy instruments adopted were; 
i) Fertilizer Subsidy which between 1976 and 1979 attracted a $75 \%$ subsidy, this was subsequently reduced to $50 \%$ percent.

ii) Liberalization import policy in respect of tractors and agricultural equipment

iii) Massive assistance programme to farmers on land clearing through cost subsides

iv) Launching of machinery ownership in 1980

(e) Agricultural Co-operative Policy:

A number of policy instruments were adopted to mobilize people for social and economic development through agricultural co-operative. These include;

i) The use of agricultural co-operatives for the distribution of farm inputs as well as imported food commodities

ii) The provision of necessary encouragement for the establishment of co-operative farms and other cooperative enterprises

(f) Water Resources and Irrigation Policy

The major instruments of water resources and irrigation policy was the establishment of eleven River Basin Development Authorities in 1977 with the overriding responsibility for the development of the country's land and water resources.

\section{Performance Of Agriculture:}

The performance of Agriculture sector from 1960 to- date, indicates a steady decline as stated earlier. From $75 \%$ contribution of the Gross Domestic Product in the mid 1960s, dropping to less than $50 \%$ of the Gross Domestic Product in mid 1990's. The commercial exploration of oil and gas in the 1970's scaled down government's emphasis on the growth of agriculture. Funding and implementation of govertment policies to the letter was, and remains a major problem for both the government and farmers as evidenced in declining agriculture budget.

There is no gain saying that agriculture is the easiest routes to Nigeria's desired level of macroeconomic diversification. This is true for four primary reasons;

(i)The sector is largely of natural endowment which confers automatic economic advantage to the country.

(ii)Processing is easy and does not require sophisticated technology and to that extent permits the ease of entry of many willing participants.

(iii)The sector is basically traditional and in congruent with our current stage in development evolution which is not yet scientifically sophisticated

(iv)With appropriate technology for variety improvements, preservation and favourable fiscal terms from the government the output of the sector will most likely be highly valued and demanded in international markets.

Statistics have thus shown that Nigerian agricultural exports are very minimal, about $0.2 \%$ of all exports. Main exports were cocoa and rubber. In the early 1970s, production of cocoa in Africa was concentrated on countries such as Ghana, Nigeria and Cote d Ivoire. Current trends indicate that these countries have maintained their markets shares of its production while Nigeria now contributes only a miserly $5 \%$ of world cocoa production while not much has been done to develop the commodity locally.

Nigeria spends close to $\$ 10$ billion on food importation annually. If invested in agriculture, this amount would have generated a high percentage of employment. The economic potentials of these resources provide growth and development. This can only be achieved with the exploitation of full potential thereby diversifying the economy.

According to Terzo, (2010) for the nation's agricultural system to be developed, it must possess certain ingredients: mechanization/technological application, access to credit and seeds, as well as acceptance of agriculture as a business venture.

Assessing the Nigeria's agricultural sector based on these criteria, it would be appreciated that the sector is yet to be developed. As Manyong et al (2003) puts it, less than $50 \%$ of the nation's cultivable agricultural land is being cultivated. Even then small holder and traditional farmers who use rudimentary techniques with the resultant low yields, cultivate most of the land. The small holder farmers are constrained by many problems including those of poor access to modern inputs and credit, poor infrastructure, inadequate access to markets, land and environment degradation, inadequate research and extension services. The underdevelopment of Nigeria's agricultural sector is further amplified when it is compared with two of its contemporaries at independence namely Brazil and Malaysia in terms of the production and consumption of fertilizer, land irrigation, and production of oil crops for which Nigeria has comparative advantage. 
Table 1

\begin{tabular}{|l|r|r|r|r|}
\hline & $\begin{array}{c}\text { Fertilizer } \\
\text { consumption } \\
\text { tonnes }\end{array}$ & $\begin{array}{c}\text { Share of arable } \\
\text { land irrigated \% }\end{array}$ & $\begin{array}{c}\text { Production of } \\
\text { oil crops (1000 } \\
\text { tonnes) }\end{array}$ & $\begin{array}{c}\text { Value of } \\
\text { Agricultural } \\
\text { exports (USD } \\
\text { million) }\end{array}$ \\
\hline Nigeria & 88,334 & 0.7 & 3503 & 564 \\
\hline Malaysia & $1,460,658$ & 4.8 & 17829 & 17,673 \\
\hline Brazil & $11,313,123$ & 4.4 & 11,677 & 42816 \\
\hline
\end{tabular}

Source: UN FAO Statistical year Book 2009

The above table shows that when Nigeria is compared with its contemporaries Brazil and Malaysia it falls far short on agricultural development. For instance it consumes by less fertilizer than both countries, again only $0.7 \%$ of Nigeria's arable land is irrigated as against $4.8 \%$ for Malaysia and $4.4 \%$ for Brazil. On production of oil crops for which Nigeria is well suited for, it is only able to produce 3,583,080 tonnes as

against 17,829,000 for Malaysia and 11,677,000 for Brazil. On revenue from export of agricultural products Nigeria records 564Million USD as against Malaysia which records 17.673 USD, and Brazil 42.816 billion USD

Table 2 Sectoral Labour Productivity (Agriculture, Industry and Services) (000)

\begin{tabular}{|c|c|c|c|c|c|c|}
\hline \multirow[t]{2}{*}{ Yeir } & \multicolumn{2}{|c|}{ Agriculture } & \multicolumn{2}{|c|}{ Industry } & \multicolumn{2}{|c|}{ sicnices } \\
\hline & $\begin{array}{l}\text { Prokluc:- } \\
\text { tivity }\end{array}$ & $\begin{array}{l}\text { Amoual } \\
\text { Circowth }\end{array}$ & $\begin{array}{l}\text { Produc- } \\
\text { tivity }\end{array}$ & $\begin{array}{l}\text { Annual } \\
\text { Growth }\end{array}$ & $\begin{array}{l}\text { Produc- } \\
\text { tivity }\end{array}$ & $\begin{array}{l}\text { Anmual } \\
\text { Cirsomith }\end{array}$ \\
\hline 1973 & 2.49 & - & 8.56 & - & 7.55 & - \\
\hline 1975 & 2.44 & 14.86 & 6.23 & -24.68 & $7 .(x)$ & -7.37 \\
\hline 1977 & 2.20 & -9.67 & 6.31 & -0.91 & 7.56 & -7.75 \\
\hline 1979 & 2.02 & -7.52 & 5.87 & -5.97 & 7.012 & -5.543 \\
\hline 1981 & 2.05 & -2.15 & 5.82 & -4.67 & 5.74 & $-1) .43$ \\
\hline 19983 & 2.11 & 1.22 & 4.78 & -13.41 & 5.61 & $-1.2 x$ \\
\hline 1985 & 2.61 & 33.81 & 5.00 & 8.11 & 5.54 & 11.22 \\
\hline 1987 & 2.32 & -5.75 & 3.84 & -5.51 & 502 & $2(1)$ \\
\hline 1989 & 2.49 & 0.57 & 6.72 & 63.35 & 4.49 & -16.51 \\
\hline $1(x \times) \mid$ & 2.44 & -1.95 & 7.11 & 5.85 & 5.30 & 18.04 \\
\hline $10 \times 91$ & 2,47 & 1.12 & 7.39 & 3.88 & 5.32 & 023 \\
\hline $19 \times 92$ & 2.47 & 0.17 & 704 & -4.70 & 5.67 & 6.76 \\
\hline 1493 & 2.45 & -1.16 & 6.69 & -4.91 & 5.56 & $-1 . x x$ \\
\hline 1994 & 2.46 & 0.71 & 6.62 & -1.15 & 5.59 & $\left(1,+4^{6}\right)$ \\
\hline 1905 & 2.45 & -0.57 & 6.34 & -4.17 & 5.36 & +14 \\
\hline $10 \%$ & 2.54 & 3.78 & 6.43 & 1.43 & $5+3$ & 1.32 \\
\hline 19097 & 2,49 & -2.01 & 6,44 & 1.40 & 5.45 & 2.24 \\
\hline $10 \times 88$ & 2.501 & -0.02 & 6.46 & 200 & 5.46 & $0.2 \mathrm{x}$ \\
\hline $14 \times 30$ & 2.51 & 1.48 & 6.46 & 1.48 & 5.43 & -132 \\
\hline $2(100)$ & 2.52 & 1.26 & 6.44 & 1.64 & $5.51)$ & 376 \\
\hline 200$) 1$ & 2.54 & 2.01 & 6.42 & -1.44 & 5.48 & $-112 x$ \\
\hline 20012 & 2.54 & -0.56 & 6.46 & 2.63 & $5.4 x$ & 1.24 \\
\hline $1974-80$ & 2.21 & 2.04 & 6.48 & -4.32 & 7.24 & -3.31 \\
\hline $1981-90$ & 2.29 & 201 & 5.16 & 3.37 & 5.27 & -11.22 \\
\hline $18(x) 1-96$ & 2.47 & 0.68 & 6.75 & $-1 .(60)$ & 551 & $-6) .+6$ \\
\hline $147+9-96$ & 2.31 & 0.41 & 5.73 & -01.23 & $5.6 x$ & -1012 \\
\hline $14 \times 97-2002$ & 2.48 & 0.96 & 5.98 & 284 & 5.4 & 6.24 \\
\hline
\end{tabular}

Nore: The growth rate was computed on the basis of the immediate past year rather than the interval of two years given in the table.

Sorerces: i. Obadan. M. I. and A. F. Odusola 2000

ii. National Manpower Board

iii. National Productivity Centre.

From the above table, we can see that over the period (1973-2002), the average labour productivity of the agricultural sector is very low and even the least when compared to the industrial and services sectors which stood respectively.

With the rapidly declining growth rate, one may be tempted to ask what have the various Government policies achieved over the years. 
Agricultural Development And Emplyoment Generation: The Nigeria Experience.

Table 3 Total Employment by Economic Activity, 2003 - 2007

\begin{tabular}{|c|c|c|c|c|c|}
\hline Description & 2003 & 2004 & 2005 & 2006 & 2007 \\
\hline Total Employment & $46,800,000$ & $48,124,440$ & $49,486,362$ & $50,886,826$ & $52,327,514$ \\
\hline Agricultural Hunting Forestry \& Fishing & $27,840,000$ & $28,516,208$ & $29,016,653$ & $29,837,824$ & $30,682,234$ \\
\hline Mining \& Quariying & 66,150 & 67,325 & 69.001 & 70,954 & 72,962 \\
\hline Manufacturing Industries & 820,000 & 838.517 & 907.877 & 933,570 & 959,990 \\
\hline Prod \& Dist. Of Electricity \& Water & 410,000 & 422,960 & 426,642 & 438.716 & 451,723 \\
\hline Building \& Construction & 260,000 & 267,879 & 273,049 & 280,777 & 288.723 \\
\hline $\begin{array}{l}\text { Comm \& Repairs of Auto \& Domestic } \\
\text { Ant. }\end{array}$ & 93,060 & 97,037 & 103.847 & 106.786 & 109,808 \\
\hline Hotels \& Restuarants & 86,940 & 89,488 & 96.370 & 99,097 & 101,901 \\
\hline Transport, Storage \& Communication & 400,000 & 412.202 & 415.988 & 427.761 & 439,866 \\
\hline $\begin{array}{l}\text { Finance Intermediation (Include } \\
\text { Insurance) }\end{array}$ & 270,000 & 275.854 & 280.948 & 288.899 & 297,074 \\
\hline $\begin{array}{l}\text { Real Estate, Renting Business } \\
\text { Activities }\end{array}$ & 58,590 & 59,983 & 60,182 & 61,885 & 63.636 \\
\hline $\begin{array}{l}\text { Public Administration \& Defience, } \\
\text { Compulsory Soc. Sec. }\end{array}$ & $4.900,000$ & 5.052 .427 & $5,067,423$ & $\begin{array}{r}5 \\
210,831 \\
\end{array}$ & $5,358,298$ \\
\hline Education ' & $8,430,000$ & 8.783 .530 & $9,473,306$ & $9.741,400$ & $10,017,082$ \\
\hline Health \& Social Wark & 280.000 & 291,431 & 296,375 & 304,762 & 313,387 \\
\hline Others & 2.885 .260 & $2,949,598$ & $2.998,702$ & $3,083,565$ & $3,170,830$ \\
\hline
\end{tabular}

Table 2 and 3 also shows the performance of agriculture measured in terms of level of employment generation and sectoral labour productivity. A quick review of these positionsrevealed that though Nigeria as an agrarian economy with a high potential, the Agricultural sector has not done very well.

III. Factors Affecting Agricultural Sector In Nigeria:

The factors militating the growth of Agricultural sector in Nigeria have been discussed by scholars such as, Olayemi (1988), Olayemi and Akinyosoye (1989), Njoku(1998), Onyeweaku(2000) and NISER (2001b). These factors include:

\section{i) Technical Constraint}

Technical constraints include the high incidence of pests and diseases, inadequate infrastructural facilities, high cost of improved varieties of seedlings, dependence on unimproved inputs and rudimentary technology as well as lack of modern techniques in agriculture. Others are inadequate extension services, inefficient inputs and distribution system, and high environmental hazards, on existent transportation networks for agricultural products.

\section{ii) Resources Constraints:}

These include shortage of labour caused by high level rural-urban migration, high demand on land due to increasing population and industrialisation, coupled with high rate of land degradation caused by oil exploration activities as well as industrial activities especially in the Niger Delta Region,a lack of friendly bank policies for agriculture.

\section{iii) Socioeconomic Constraints:}

These include scarcity and high cost of improved farm inputs, inefficient marketing arrangement characterized by high marketing margins, lack of grades and standards, lack of legally enforceable ownership of lands as well as extension and credit, low rate of growth in international demand for primary export commodities,poor road network as well as a lack of storage facilities.

\section{iv) Organizational Constraints}

Agricultural production is predominantly in the hands of a multitude of small scale unorganized farmers, scattered across the country. Lack of organization, coupled with the dispersed nature of farm settlements, 
hinders the participation of farmers in agricultural and rural development. It also hinders the supply of extension service, farm credit, and other vital inputs to farmers.

\section{RECOMMENDATION}

In this paper, agriculture is recognised as an underdeveloped sector underdeveloped, a situation that is most undesirable. Thus for agriculture to have its rightful place as stimuli for growth,developtment, a major foreign exchange earner and employee of labour,certain policy areas must be pursued to achieve this objective.

(i) Credit extension to small holder farmers;

As mentioned the small holder farmers constitute a significant percentage of the agricultural sector. Most of these farmers lack access to credit and so are unable to increase their level of production. The government must thus ensure adequate extension of credit to such farmers.

Although,credit schemes for farmers exist,government must ensure that such credits get to the actual farmers that need them.

ii) Extension Services: Provision of extension services is also very important for agricultural development. Technical advice and counsel to farmers is necessary for agricultural development.Extension agents should be well equipped in terms of mobility,so as to take their services to the hinterlands.

iii) The lack of access to land for peasant rural farmers is also a factor militating against the development of the agricultural sector in the country. It is important for the government at all level to partner with farmers to allocate land to them and also ensure that land so allocated, are used for the agricultural purpose.

iv) Mechanization: For agricultural sector to be developed and employment generated there must be a shift from the traditional methods of farming to a more technologically advanced/mechanized method of farming and high yielding methods of planting.

v) Price monitoring and Stability;

Price stabilization is necessary if farmers would make returns from their investments. Farmers are usually discouraged, when low returns are gotten after sales of their products. The government should provide a ready market,buying from small scale farmers and selling to the bigger markets. This helps to erase the role of middleman in the selling iof agricultural products.and thus helps keep prices stable.

vi) Storage Facilities;

Storage of agricultural products is a major factor affecting the growth of agricultural sector.Looses experienced after harvesting is very discouraging. It is imperative for the government to put in place a system of ensuring adequate storage of harvested produce as this will stand as a sure way of encouraging farmers and thereby increasing production.

vii) Specialization- The government in this regard has to encourage states plus regions to specialize in commodities for which they have a comparative advantage. The effect of this is that all energy in that region will be geared towards those commodities, thus increasing productivity, creating employment and export.

viii) Priority Attention - The government at all level must take the development of agriculture as national priority. The is very important because oil and gas are exhaustible natural resources whereas agricultural resources if well developed can sustain the economy for as long as possible given the nation's endowment in that sector. The government should dedicate a larger percentage of its annual budget to the development of the agricultural sector.

\section{Conclusion}

It is generally acknowledged that Agricultural development contributes so much in reducing unemployment and economic growth of any nation.

Nigeria has an enormous agricultural potential and successive governments at various levels have pursued several policy frameworks and programmes to turn the fortunes of the nation's agricultural sector around.

However, in this review, it is shown that the development of Agriculture in Nigeria is still at a very low level and is yet to take advantage of of the potentials of the country,in terms of climate,land and human resources. Thus, some major problems affecting the development of the sector in Nigeria were highlighted here and appropriate recommendation made.

\section{References}

[1] Adebolaetal (1972) Agricultural Science for West Africa Schools and Colleges, London W.I. Oxford University Press, Ely House.

[2] Adedipe, N.O. (1999) Fluxes, forces and flash flosses in Nigeria Agriculture University of Agriculture, AbeokulaAlunmi Association

[3] Ajakaiye, O (1997) The Structural Adjustment Programme and changes in the Structure of production in Nigeria, 1986-1994 NCEMA Monograph Series No.9 Nigeria 
[4] Akande, S.O ( 1998) Public Policy in Nigeria Agriculture" in Institutional Reforms for agriculture development (Ed Oludimu, O.L and Imodu P.B) Triumph Books Publishers

[5] Akinboloba, A (2001) Globalization and its impact on the Emergent States: An Analysis of its Problems and Prospects in Brazil and Nigeria, Lagos Concept Publications Brown, L etal (2000) The World Book Encyclopedia of peoples and places, Vol.1 Chicago World Book Inc.

[6] Central Intelligence Agency (2007) Brazil: Agriculture Overview CIA World Fact Dike, N (1987) the Processes and trends in Agricultural decline and food Crisis in Nigeria" department of economics seminar presentation, A.B.U Zaria

[7] Eboh E.C (2003) Competitiveness and performance of Nigeria Agricultural Sector 1992-2001, Research report submitted to World Bank Nigeria Country office Abuja

[8] Eicher, C and WLH (1964): Agriculture in Economic Development, New York FAO (1992) Proceeding of the 1992 World Food Day Symposium, Food and Agriculture Organisation of the United Nations, Rome Graham G. H, Gauthier H, \& De Darro JRM (1987): Thirty years of Agricultural Growth in Brazil, Crop performance, Region Profile and Recent Policy Review, Economic change, Vol. 36 no.1 1987

[9] Humbert, J.N. (2000): The Multifunctional Role of Agriculture, Proceeding of $7^{\text {th }}$ World Sugar Conference Durban, www.surgaronline .com/sugarindustry/index

[10] Idris, M (1994) The processes and Trends in Agricultural Decline and Food Crises in Nigeria. B.Sc unpublished thesis Iwayemi, A (2000) FA-PRESA, National Review Workshop on Investment for Report prepared Prepared for the international labour organization

[11] Idachaba, F (2002), A framework for agricultural policy process analysis', Proceeding of a CTA Workshop, Entebbe, Uganda P6-10 Jerome A and Associates (1999) Private Sector Investment jobs for Africa/ Presa Nigeria Investment for poverty -reducing Employment (IPRE) Study, Interim Report

[12] Metz H.C (1991) Nigeria: A country Study, Washington GP FOR Library of Congress Monyong V.M, (2003) Agriculture in Nigeria: Identifying Opportunities for Increased Commercialization and Investment USAID/Nigeria

[13] Njoku , P.C (1998) " Nigeria Agriculture, and the challenges of the $21^{\text {st }}$ Century Faculty Lecture, Faculty of Agriculture, University of Nigeria Nsukka Nigeria Investment promotion Commission (2003) " Agricultural sector Profile (Unpublished)

[14] Nyako, M.(2006) " Opportunities and challenges in modernizing agriculture In Kano" Paper presented at Kano state economic summit Okuneye, P.A (1995) "Nigeria Agriculture on the run, Refuses to move "'

[15] University of Agriculture, Abeokuta inaugural lecture Series No.236p Olayemi J.K and V.O.Akinyosoye (1989) " A Review of the Nigeria " Economy and the Agricultural Sector" IACU-IFAD Research Report Olayemi J.K (1988) " Agricultural Policies and programs in Nigeria (Unpublished Paper)

[16] Onu K.C (2005) " Technology Transfer and Agricultural Entrepreneurship in Nigeria" Paper delivered at $4{ }^{\text {th }}$ National Economic Summit Group (NESG) on Agriculture, Kwara State

[17] Okunmadewa, F and J.K Olayemi (1999) " Nigeria Globalization, Policy Changes Agricultural Research and development ", Commissioned Technical Technical Report Prepared for ISNAR, the Hague Terzo Geri (2010) what is Agricultural Development http: //www.wisgeek.com/what is agricultural- development.htm Wilber, C.K.and Jameson, K.P (1992) Political Economy of Development and Under Development, R.R.Donnelley\& Sons Company, United State of America. 